\title{
Effect of Online Systems Quality, Banking Service Product Quality and Customer Trust on the Success of BRI Syari'ah E-Banking Information System
}

\author{
Karmawan, Suhaidar \\ Universitas Bangka Belitung, Indonesia \\ karmawan77@gmail.com
}

\begin{abstract}
This study will discuss and to find out and test whether Online Systems Quality, Banking Service Product Quality and Customer Trust are thought to influence the Success of E-Banking Information System in one of the Shariah Banks in Pangkalpinang City. This research is quantitative research, using primary data, the instrument used is a questionnaire given to respondents. The population in this study is the Customer of BRI Bank Syari'ah PangkalPinang Branch, while the sampling technique used is convenience sampling technique. The data of this study will be processed and analyzed by Multiple Linear Regression tests with the aim to find out how far the knowledge and level of understanding of Online Systems Quality, Banking Service Product Quality and Customer Trust are thought to influence the success of E-Banking Information System in BRI Sharia Banks in Pangkalpinang.
\end{abstract}

\section{Article Info}

- Received : October 30, 2018

- Revised : November 7, 2018

- Published : January 5, 2019

- No. Pages : 116-127

- DOI : 10.33019/ijbe.v3i1.113

- JEL : G21, L15

- Keywords : online systems quality, product quality banking service, customer trust, ebanking information system

\section{Introduction}

The existence of internet banking has brought changes in the type of banking services, from the original banking delivery channels to the direction of self-service channels. Internet technology can eliminate time and space boundaries, be global/international even without borders. For banks, services through internet banking can reduce operational costs because they can save paper, human resources, and do not need to invest in ATMs or branch offices. Today's information and communication technology have progressed very rapidly which has changed the company's business strategy and has also encouraged innovation in the service sector including banking services. Currently, banks are not only competing in traditional banking services but are also expanding the scope of competition for information technology and communication with internet banking services. 
Indonesian banks currently offer internet banking services to make it easier for customers to conduct banking transactions. The development of internet banking transactions continues to increase. According to a survey conducted by Sharing Vision (2014) shows that internet banking transactions in 2013 were greater than the value of ATM / Debit card transactions and credit cards. Although ATMs are still in great demand, the transaction value is still inferior to internet banking.

As a form of service and competitive strategy tools, the ultimate goal of using internet banking is to achieve the success of the internet banking information system. A sophisticated internet banking system can also pose a greater risk, as well as an increase in insecurity for customers, so it does not provide added value to banks or customers (Irsyad, 2008). However, in practice, raises the question of whether the internet banking information system has been successful in its application. The success of the internet banking information system needs to be evaluated, and identified determinants than the following as problems Damage to technology facilities to support E-Banking services and poor quality of human resources as a driver of a banking company.

The collapse of the security system and customers' personal data in E-Banking services Online system service process when accessing the E-Banking web when the server is damaged or maintenance. Error in the system so that the data generated is not in accordance with what is inputted by the customer. Several factors influence the success of the internet banking information system. From various studies, there are several factors identified that influence the success of information systems. This study uses three variables, namely online systems quality, banking service product quality, and customer trust affect the success of the internet banking information system, especially in one of the Islamic Banks.

Online information quality system is the quality of information systems owned by banks in providing their services online and is one dimension of internet banking service quality (Jun and Cai, 2001). If the information display layout in the internet banking web is easy to understand, transactions using internet banking easy to do, the waiting time in searching for information on internet banking usage is very short, and the information presented is very accurate and safe in the transaction, then the customer will feel satisfied in using internet banking. So, the success of information systems can be achieved because user satisfaction is an indicator of system success. Banking service product quality is the quality of the internet in providing its services online and is one dimension of internet banking service quality (Jun and Cai, 2001). If internet banking can provide features/features such as what customers want, can provide benefits, all services are on the menu, offer many banking service packages, and can provide many useful free services to customers, then internet banking users will be satisfied. So that the success of the information system will be achieved.

Customer trust is a customer's willingness to trust others in the exchange process (Wong and Sohal, 2006). Customer satisfaction and trust in e-Banking services have been considered as an important theoretical and practical issue (Ala Eddin and Hasan, 2011). Trust is the belief that the word or promise of a party is reliable and a group will fulfil its obligations in the Rotter exchange relationship in (Alsheyyab and Dalbir Singh, 2013). Trust in e-banking transactions is very important to ensure safe transactions take place. With the achievement of security in this 
transaction will maximize user satisfaction (Alsheyyab and Dalbir Singh, 2013). Achieving user satisfaction means achieving the information system objectives that are expected or successful in achieving the objectives of the information system.

Jun and Cai's (2001) research shows that Customer service quality, online systems quality, and banking service product quality affect the satisfaction of internet banking customers. Alsheyyaband Singh (2013) shows that the results of this review are that trust is the effective function center of the system e-banking. Banks in Indonesia are currently providing internet banking services. One of them is BRI Syari'ah which continues to carry out business transformation strategies and increase competitiveness through the implementation of information technology. The use of information technology can capture a surge in Bank transactions independently.

\section{Literature Reviews}

\section{Online Systems Quality}

The service quality model that is popular and has become a reference in service research is the Servqual model. This Servqual model is closely related to the customer satisfaction model; which is largely based on the disconfirmation approach. According to the morphological approach, if the performance of an attribute increases greater than the expectation of the attribute in question, then satisfaction (and the quality of services) will increase. According to Tjiptono (2007) in the Servqual model, there are five dimensions of service quality consisting of reliability, responsiveness, assurance, empathy, and tangible. Some studies modify the Servqual model that is suitable or relevant to internet banking conditions. According to Jun and Cai (2001), the dimensions of service quality for internet banking are Online Customer service quality is the quality of service or quality of services provided by internet banking, Online systems quality, namely the quality of information systems owned by banks in providing their services online and Banking services product quality is the quality of bank products in providing services online.

\section{E-Banking/Internet Banking}

The concept of e-Banking has been defined in various ways (Daniel, 1999 in Dixit and Saroj K. Dakatta, 2010). According to Karjaluoto (2002) in Dixit and Saroj K. Dakatta (2010) e-Banking is a construct consisting of several distribution channels. Daniel (1999) in Dixit and Saroj K. Dakatta (2010) defines e-Banking as the distribution of banking information and services to customers through different delivery platforms that can be used with different terminal tools such as PCs and mobile phones with browsers or desktop software, digital telephone and television. EBanking transactions can be done anywhere as long as there is a data service network and can access 24 hours and real time. E-Banking is a banking service that includes Internet Banking, Mobile Banking, SMS Banking and Phone Banking (www.bi.go.id).

Bank Indonesia (2004) states that internet banking is one of the banking services that allow customers to obtain information, communicate and conduct banking transactions through the internet network. Types of internet banking activities are divided into three, namely Informational Internet Banking, Communicative Internet Banking, and Transactional Internet Banking. Internet banking is defined as the use of the internet to conduct banking activities such as transferring funds, paying bills, seeing savings balances, buying financial instruments and 
certificates of deposit (Singhal and Padhmanbhan, 2008). According to Turban et al., (2002) in Nurastuti (2011) internet banking is banking that uses the internet that allows payment of bills, obtaining loans from banks, or making transfers between accounts. Banks can offer internet banking in two ways (Baloach et al. 2010), the first existing bank with a physical office providing web and offering internet banks as an additional traditional service channel. Second, banks build a branch with services through the internet or virtual banks.

\section{Banking Services Product Quality}

A popular service quality model and until now a reference in service research is the Servqual model. This Servqual model is closely related to the customer satisfaction model; which is largely based on a disconfirmation approach. According to the disconfirmation approach, if the performance of an attribute increases more than the expectation of the attribute concerned, then satisfaction (and service quality) will increase. According to Tjiptono (2007) in the Servqual model, there are five dimensions of service quality consisting of reliability, responsiveness, assurance, empathy, and tangible. Some studies modify Servqual models that are suitable or relevant to internet banking conditions.

\section{Customer Trust}

Customer satisfaction and trust in e-Banking services have been considered as an important theory and practice issue (Ala'Eddin and Hasan, 2011). Customer trust is a customer's willingness to trust others in the exchange process (Wong and Sohal, 2006). According to Rotter in Alsheyyab and Singh (2013) trust is the belief that the word or promise of a party is reliable and a group will fulfil its obligations in an exchange relationship. Trust in e-banking transactions is very important to ensure safe transactions that maximize user satisfaction (Alsheyyab and Dalbir Singh, 2013). According to Anderson and Narus inWong and Sohal (2006), the concept of trust emphasizes the willingness of someone to do an action that brings positive results to other parties.

\section{The Success of Information Systems}

The success of information systems is not defined in the literature. This study uses the success of information systems from DeLone and Mclean (1992), which developed a model which they called the success model of the DeLone and Mclean information system (D \& M Success Model). This proposed model reflects the dependence of six information system success measurements. Satisfaction is a feeling of pleasure or disappointment that results from comparing the performance of a product in a relationship with its expectations (Kotler and Keller, 2006). Paul et al., (2010) defines that customer satisfaction is the number of customers, or the percentage of total customers, who report their experience with a company, product, or service exceeding certain satisfaction goals.

The tight competition, where more and more producers are involved in meeting customer needs and desires, causing each company to place an orientation on customer satisfaction as the main objective. This is reflected in the increasing number of companies that include their commitment to customer satisfaction in their mission statements, advertisements, and public relations releases. Engel et al. in Tjiptono (2007) state that customer satisfaction is a post-sale evaluation where the chosen alternatives are at least equal or exceed customer expectations, while dissatisfaction arises when the results (outcomes) do not meet expectations. Customer satisfaction is the level of 
one's feelings after comparing the performance (or outcome) he feels compared to his expectations (Kotler, 2006).

\section{Conceptual Framework}

It is suspected that Online Systems Quality (OS), Banking Service Product Quality (BS) and Customer Trust (KN) on The Success of E-Banking Information Systems (KS). This study replicates the research of Balasubramanian et al., (2014) by adding trust or trust variables from research (Alsheyyab and Singh, 2013).

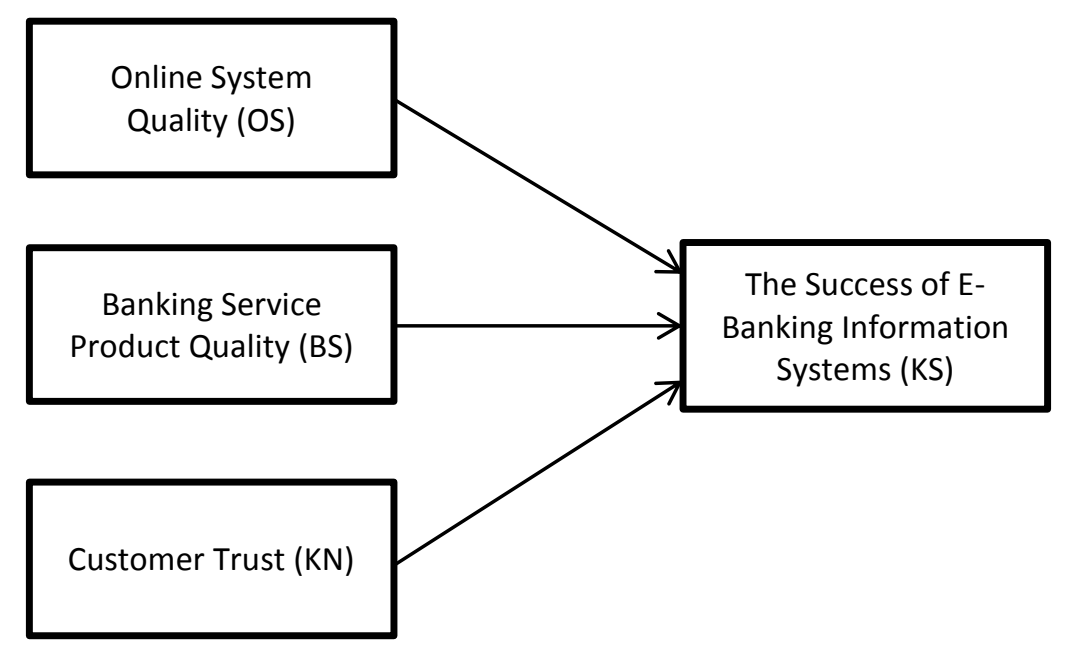

Figure 1. Conceptual Framework

\section{Hypothesis}

Based on the framework above, the hypothesis is as follows:

Ha1: Online Systems Quality has a positive effect on The Success of E-Banking Information Systems.

Ha2: Banking Service Product Quality has a positive effect on The Success of E-Banking Information Systems.

Ha3: Customer Trust has a positive effect on The Success of E-Banking Information Systems.

\section{Research Methods}

\section{Research Types and Approaches}

This research is quantitative research which is an analysis analyzed. Therefore, in quantitative research the measurement of the observed symptoms becomes important, so data collection is done using a list of questions arranged based on measurements of the variables studied which then produce quantitative data. Variable approaches used in this study include:

1. Independent variables are Online Systems Quality, Banking Service Product Quality, and Customer Trust.

2. The dependent variable is the variable which is influenced by the independent variable. In this study, the dependent variable is The Success of E-Banking Information Systems. 
The population is a collection of all similar elements but can be distinguished from each other. The population in this study was several BRI Syari'ah customers in the Pangkalpinang branch. While research sample consists of some selected members of the population where after calculation through Slovin theory there are 100 samples. The data used in this study are primary data and secondary data with questionnaires as a research instrument.

\section{Measurement Scale}

According to Sugiyono (2008), the Likert scale is used to measure attitudes, opinions, and perceptions of a person or group of people about social phenomena. In research, this social phenomenon has been specifically determined by researchers, from now on referred to as the research variable. With a Likert scale, the variables to be measured are translated into variable indicators. Then the indicator is used as a starting point to compile instrument items that can be statements that must be answered by the respondent. The instrument measurement used in this study used a Likert scale by filling out questionnaires arranged in the form of question sentences and respondents were asked to fill in the questionnaire by giving a checklist $(\sqrt{ })$ on the questionnaire answer sheet.

The answers to each instrument item used in the Likert scale have a gradation from very positive to very negative which can be in the form of the following words:

- Strongly agree, given a score $=5$

- Agree, given a score $=4$

- Simply agree, given a score $=3$

- Disagree given a score $=2$

- $\quad$ Strongly disagree given score $=1$

\section{Statistical Analysis}

Statistical analysis consisted of descriptive statistical analysis and multiple regressions.

a) Descriptive statistical analysis is an analysis using a statistical approach or formula and is accompanied by tables in addition to explanations.

b) Multiple Regression Analysis

Data obtained from the table will be analyzed by multiple regression analysis so that it is easily understood and interpreted. This model will describe the influence of the variables studied by entering data in the table from the recapitulation of the questionnaire. Data processing is done with SPSS Version 20.0.

\section{Results and Discussion}

\section{Results of Research Data Analysis}

Questionnaires were distributed in various places and the BRI Syari'ah Office by meeting customers who were queuing at the bank's office. The distribution of questionnaires was carried out during May - September 2018. Most of the customers met were not willing to fill out the questionnaire because they were very concentrated in waiting for the queue and busy with their activities while waiting for their turn. From 100 questionnaires distributed, 28 questionnaires were failed to process. The composition of the questionnaires distributed can be seen in Table 1 below: 
IJBE (Integrated Journal of Business and Economics)

e-ISSN: 2549-3280/p-ISSN: 2549-5933

Table 1. List of Questionnaires Distributed

\begin{tabular}{|l|c|c|}
\hline \multicolumn{1}{|c|}{ Description } & Total & Percentage \\
\hline Distributed Questionnaire & 100 & $100 \%$ \\
\hline Rejected & 10 & $10 \%$ \\
\hline Valid Questionnaire & 90 & $90 \%$ \\
\hline The questionnaire that is not filled in completely & 18 & $18 \%$ \\
\hline Questionnaires that can be processed & 72 & $72 \%$ \\
\hline
\end{tabular}

Source: Data Processed, 2018

Table 1 showed that the questionnaire that was rejected or not willing to be filled out by the respondents as many as 10 forms or $10 \%$ of the total questionnaires distributed. While the questionnaire that was not filled completely was 18 or $18 \%$. Questionnaires that can be processed as many as 72 forms or $72 \%$ of the number of questionnaires distributed.

\section{Validity Test}

Validity testing is useful for measuring the accuracy of an item in a questionnaire or scale (Priyatno, 2010). A questionnaire is said to be valid if the questions on the questionnaire can reveal something that will be measured by the questionnaire. Based on the results of the data, the values of r-table or degree of freedom $(\mathrm{df})=\mathrm{n}-2$, where $\mathrm{n}=72$, then $\mathrm{df}=72-2=70$ with a significance level of 0.05 , obtained $\mathrm{r}$-table $=0.2319$. Validity test results indicate that all questions or statements are declared valid.

\section{Reliability Test}

In this study, the reliability test was tested using the Cronbach Alpha statistical test.

Table 3. Reliability Test

\begin{tabular}{|l|c|c|c|}
\hline \multicolumn{1}{|c|}{ Variable } & $\begin{array}{c}\text { Cronbach Alpha } \\
(\alpha)\end{array}$ & $\begin{array}{c}\text { Standard } \\
\text { Value }\end{array}$ & Explanation \\
\hline Online systems quality & 0,824 & 0,70 & Reliable \\
\hline Banking service product quality & 0,703 & 0,70 & Reliable \\
\hline Customer trust & 0,735 & 0,70 & Reliable \\
\hline The Success of E-Banking Information Systems & 0,710 & 0,70 & Reliable \\
\hline
\end{tabular}

Source: Data Processed, 2018

Table 3 shows that the Cronbach Alpha value of all variables has a Cronbach Alpha value greater than 0.70 which means that the variable online systems quality, banking service product quality, customer trust, and the success of information systems are reliable.

\section{Normality Test Results}

The purpose of the normality test is to test whether, in the regression model, confounding or residual variables have a normal distribution. If this assumption is violated, the statistical test becomes invalid for a small sample number. There are two ways to detect whether graph analysis and statistical tests normally distribute the residuals. One of the easiest ways to see residual normality is to look at a histogram chart that compares observation data with distributions that are close to normal distribution. Graph analysis consists of graph histogram of Regression 
Standardized Residual. If the histogram chart does not deviate right and left, then the data is normally distributed.

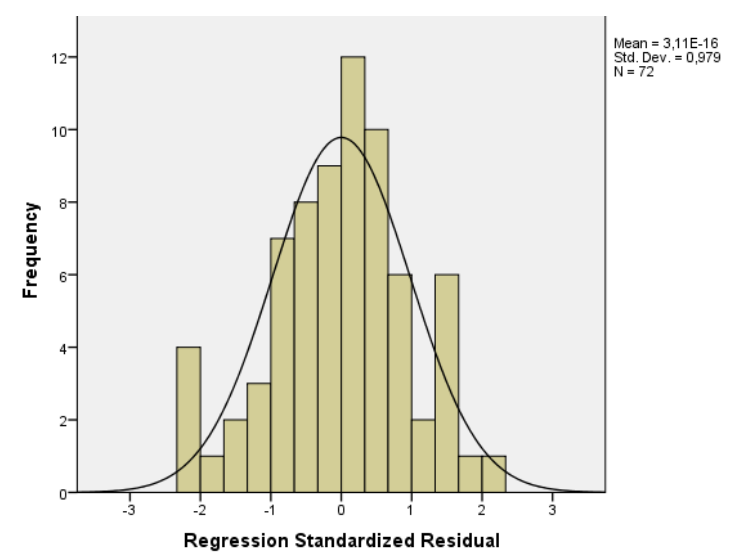

Figure 2. Histogram Graphs

It can be seen that the histogram chart does not deviate to the right and the left, the research data can be said to be normally distributed, so it can be concluded that the data is normally distributed.

\section{Multicollinearity Test}

The purpose of the Multicollinearity test is to test whether the regression model is found to correlate independent (independent) variables. A good regression model should not find any correlation between independent variables.

Table 4. Multicollinearity Test

\begin{tabular}{|c|c|}
\hline Tolerance & VIF \\
\hline 0,863 & 1,158 \\
\hline 0,820 & 1,220 \\
\hline 0,720 & 1,388 \\
\hline
\end{tabular}

Source: Data processed, 2018

It can be seen that the VIF values for Online Systems Quality (OS), Banking Service Product Quality (BS), and Customer Trust (KN) values are 1,158 1,220; and 1,388. Because the VIF value is less than 5 , it can be concluded that there is no multicollinearity problem in the regression model.

\section{Heteroscedasticity Test}

The purpose of heteroscedasticity test is to test whether in the regression model there is a variance inequality from residual one observation to another observation. A good regression model is one that does not occur heteroscedasticity. 


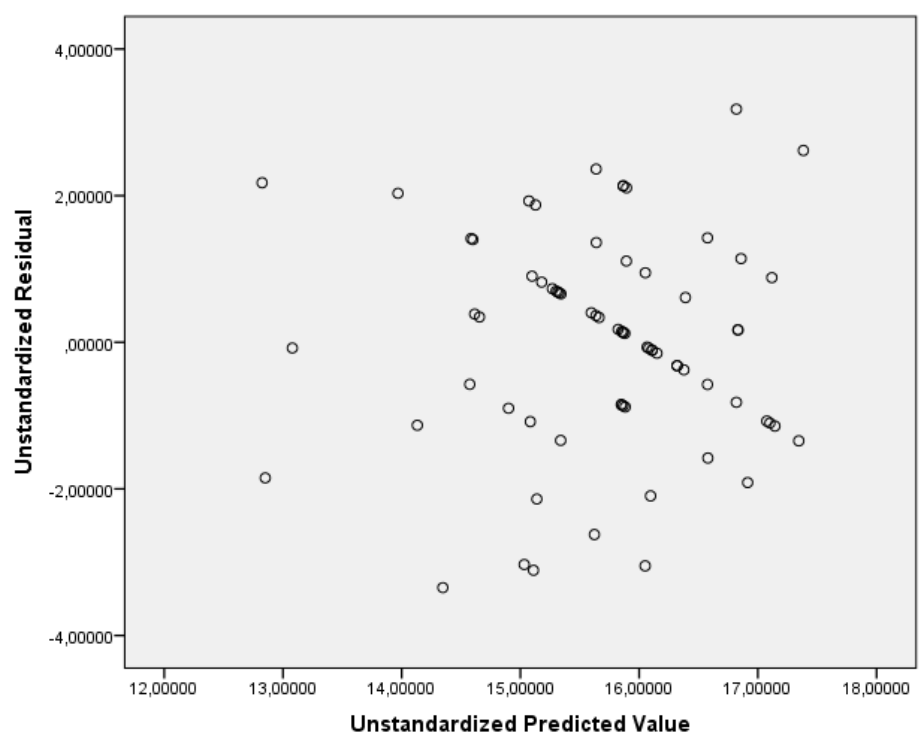

Figure 3. Scatterplot Graphs

Display data of Figure 3 shows that the point spreads on the Y-axis, and spreads above and below 0 . This shows that the regression model found no heteroscedasticity problem.

\section{Multiple Linear Regression Analysis}

The research hypothesis was tested using multiple regression analysis. Based on the results of data processing with the SPSS application, the following results are obtained:

Table 5. Multiple Linear Regression Result

\begin{tabular}{|c|c|c|c|c|c|c|}
\hline \multicolumn{7}{|c|}{ Coefficients } \\
\hline & \multirow[t]{2}{*}{ Model } & \multicolumn{2}{|c|}{$\begin{array}{l}\text { Unstandardized } \\
\text { Coefficients }\end{array}$} & \multirow{2}{*}{$\begin{array}{c}\begin{array}{c}\text { Standardized } \\
\text { Coefficients }\end{array} \\
\text { Beta }\end{array}$} & \multirow[t]{2}{*}{$\mathrm{t}$} & \multirow[t]{2}{*}{ Sig. } \\
\hline & & $\mathrm{B}$ & Std. Error & & & \\
\hline & (Constant) & 7,694 & 1,906 & & 4,037 & ,000 \\
\hline & Online System Quality & 242 & 082 & ,317 & 2,932 & ,005 \\
\hline & Banking Service Product Quality & , 013 & 101 & 014 & 129 & ,898 \\
\hline & Customer Trust & ,256 & 085 & ,357 & 3,017 & ,004 \\
\hline
\end{tabular}

a. Dependent Variable: The Success of E-Banking Information Systems

Source: Data Processed, 2018

The unstandardized coefficients section B; the multiple linear regression equation is obtained as follows:

$\mathrm{KS}=7,694+0,242 \mathrm{OS}+0,013 B S+0,256 \mathrm{KN}$

KS : The Success of E-Banking Information Systems

OS : Online Systems Quality

BS : Banking Service Product Quality

$\mathrm{KN}$ : Customer Trust 
The t-test shown in Table 6 below is conducted to determine the relationship between independent variables on the dependent variable individually (partial). In this study, all variables significantly influence The Success of E-Banking Information Systems variable (KS), except Banking Service Product Quality variable (BS).

Table 6. T-Test Results

\begin{tabular}{|c|c|c|}
\hline Variables & $\mathrm{t}$ & Sig. \\
\hline Online System Quality & 2,932 &, 005 \\
\hline Banking Service Product Quality &, 129 &, 898 \\
\hline Customer Trust & 3,017 &, 004 \\
\hline
\end{tabular}

Source: Data processed, 2018

Meanwhile, Simultaneous testing results (F-test) can be seen below:

Table 7. F-Test

\begin{tabular}{|l|l|c|c|c|c|c|}
\hline \multicolumn{8}{|c|}{ ANOVA } \\
\hline \multirow{4}{*}{1} & Model & Sum of Squares & df & Mean Square & F & Sig. \\
\cline { 2 - 8 } & Regression & 67,913 & 3 & 22,638 & 10,306 &, $000^{\text {b }}$ \\
\cline { 2 - 8 } & Residual & 149,365 & 68 & 2,197 & & \\
\cline { 2 - 8 } & Total & 217,278 & 71 & & & \\
\hline
\end{tabular}

a. Dependent Variable: The Success of E-Banking Information Systems

b. Predictors: Customer Trust, Online System Quality, Banking Service Product Quality

Source: Data processed, 2018

Table 7 Shows that all variable simultaneously significance at 0,000 . This significance value is less than 0.05, which means that simultaneously all the independent variables consisting of Online Systems Quality, Banking Service Product Quality, and Customer Trust simultaneously significantly influence The Success of E-Banking Information System.

\section{Determination Coefficient Test}

The coefficient of determination (R Square) is essentially used to measure how far the ability of the model in explaining the dependent variable. Whether or not the estimated regression model must also be assessed by testing using the Coefficient of Determination (Goodness of Fit) or can be denoted by (R Square).

Table 8. Determination Coefficient Test Results

\begin{tabular}{|c|c|c|c|c|c|}
\hline \multicolumn{7}{|c|}{ Model Summary } \\
\hline Model & $\mathrm{R}$ & R Square & Adjusted R Square & $\begin{array}{c}\text { Std. Error of the } \\
\text { Estimate }\end{array}$ & Durbin-Watson \\
\hline 1 &, $559^{\mathrm{a}}$ &, 313 &, 282 & 1,48207 & 1,806 \\
\hline
\end{tabular}

Source: Data processed, 2018 
Based on Table 8 , results of the overall regression analysis where the R-value $(0,559)$ which means that the correlation or relationship between the success of information systems with online systems quality, banking service product quality, and customer trust is strong. The $\mathrm{R}$ square value or the coefficient of determination is 0,313. Its show that The Success of E-Banking Information System as the dependent variable can be explained by Online Systems Quality, Banking Service Product Quality and Customer Trust by $55.90 \%$, while the remaining $44.10 \%$ is explained by other variables which not explained in this study.

\section{Conclusion and Suggestion}

\section{Conclusion}

Based on the results of the analysis of the data collected, the following conclusions can be drawn:

1. Online Systems Quality has a positive effect on The Success of E-Banking Information Systems.

2. Banking Service Product Quality has a positive effect on The Success of E-Banking Information Systems.

3. Customer Trust has a positive effect on The Success of E-Banking Information Systems.

\section{Limitations}

This study has limitations that can be described as follows:

1. This research has weaknesses, namely time and very minimal funding.

2. The results of this study are difficult to generalize because they are only carried out at BRI Syari'ah Branch of Pangkalpinang.

\section{Suggestion}

Based on the results of this study, can provide some suggestions as follows:

1. Research can then add other variables as a predictor of the success of the Internet Banking information system.

2. Further research is expected to expand the survey area or object.

3. The quality of user performance, trust in the system and interaction service interaction simultaneously in developing electronic systems banking has been proven to increase effectiveness system with user satisfaction as an indicator.

4. The power is underlying the quality of internet banking services, namely communication, customer participation channels, service facilities, human resources, technology infrastructure and norms. The six strengths of internet banking services are dimensions of competitive power in the banking industry.

\section{References}

1) Ala`Eddin, M.K.A. and A.A. Hasan, (2011). E-banking functionality and outcomes of customer satisfaction: An empirical investigation. Int. J. Market. Stud., Vol.3. No. 1.

2) Alsheyyab, Ma'en Mahmoud Ali and Dalbir Singh. (2013). Effect of Trust on E-Banking User's Satisfaction: A Review. Research Journal of Applied Sciences, Engineering, and Technology. Vol. 5 No. 4. 
3) Dixit, Neha, and Saroj K. Datta. (2010). Acceptance of E-banking among Adult Customers: An Empirical Investigation in India. Journal of Internet Banking and Commerce. Vol. 15. No.2.

4) Hoppe, Rudi., Paul Newman., dan Pauline Mugera. 2001. Factors Affecting the Adoption of Internet banking in South Africa: a Comparative Study, ER Project, in Partial Fulfillment of the Requirements for The Course on Information Systems Honours (INF 414 W).

5) Irsyad M. 2008. Internet Banking: Sistem Informasi Perbankan yang Bernilai Tambah, Koch TW, MacDonald SS. 2003. Bank Management. 5thEdition. Thomson.

6) Jun, Minjoon dan Shaohan Cai. (2001). The Key Determinants of Internet Banking service Quality: a content analysis. International Journal of Bank Marketing. Vol. 19. No. 7.

7) Kotler, P, and K. Keller, (2006). Marketing Management. New Jersey: Pearson Education Inc.

8) Kumbhar, V. M. (2011). Factors Affecting The Customer Satisfaction In E-Banking: Some Evidences Form Indian Banks. Management Research And Practice. Vol. 3. No. 4.

9) Nimako, et al., (2013). Customer Satisfaction With Internet Banking Service Quality In The Ghanaian Banking Industry. International Journal Of Scientific \& Technology Research. Vol. 2. No.7.

10) Paul, W.Neil, T.Bendle Philipe \& David, Reibstein.Marketing metrics: The definitive guide to measuring marketing performance Upper saddle river. New Jersey: Person Education, Inc.

11) Singhal, D and V. Padhmanabhan (2008). A Study on Customer Perception Towards internet Banking: Identifying major contributing factors. The Journal of Nepalese Business Studies. Vol. 1.

12) Tan, Margaret., Thompson S. H., \& Teo. (2000). Factors Influencing the Adoption of Internet Banking, Journal of the Association for Information Systems, July, Vol 1, No 5.

13) Tong, Canon., Stanley Kam-Sing Wong., dan Ken Pui-Hing Lui. 2012. The Influences of Service personalization, Customer Satisfaction and Switching Costs on E-Loyalty, International Journal of Economics and Finance. Vol. 4, No. 3.

14) Wong, A. and Sohal, A. (2006). Understanding the Quality of Relationship in Consumer Services. International Journal of Quality \& Reliability Management. Vol. 23 No. 3. 